\title{
4-OSIOS PRAMONĖS REVOLIUCIJOS IŠŠŪKIAI MOKESČIŲ SISTEMAI IR PERTVARKOS KRYPTYS
}

\author{
*Jevgenija Česnausk $\dot{e}^{1}$, Astrida Miceikien $\dot{e}^{2}$ \\ ${ }^{1}$ Dokt. Vytauto Didžiojo Universitetas. Universiteto g. 10, Akademija, Kauno raj., Lietuva. \\ El.paštas jevgenija.cesnauske@vdu.lt \\ ${ }^{2}$ Prof. dr. Vytauto Didžiojo Universitetas. Universiteto g. 10, Akademija, Kauno raj., Lietuva. \\ El.paštas astrida.miceikiene@vdu.lt
}

Pateikta 202006 22; Priimta 20200831

\begin{abstract}
4-ają Pramonès revoliuciją galima laikyti šiuolaikinio ekonominio, socialinio ir kultūrinio progreso terpe, kurioje visi vykstantys evoliucijos procesai paremti skaitmeninėmis sistemomis. Šie procesai sukuria tokius iššūkius mokesčių sistemai: robotizacija, skaitmenizacija ir kitos technologinès inovacijos. Mokesčiu sistema turi adaptuotis prie 4-osios Pramonès Revoliucijos kuriamų pokyčių, išnaudoti jų potencialą ir užtikrinti ekonomikos plètrą, stabilias biudžeto pajamas, teisingą ir proporcingą mokesčių paskirstymą. Tyrimo mokslinė problema: kokios galimos mokesčių sistemos pertvarkos kryptys 4-osios Pramonès revoliucijos iššūkių kontekste, siekiant užtikrinti pakankamas mokestines pajamas? Tyrimo tikslas - identifikuoti 4-osios Pramonès revoliucijos keliamus iššūkius mokesčių sistemai ir galimas pertvarkos kryptis. Tikslui pasiekti buvo išanalizuoti ir susisteminti mokslininkų tyrimai ir tarptautinių organizacijų ekspertų ataskaitos naudojant operacionalizacijos, sisteminès analizès, indukcijos ir dedukcijos metodus. Gauti tyrimo rezultatai numato dvi mokesčių sistemų tobulinimo kryptis: naujų mokesčių įvedimas ir esamų mokesčių sistemų pertvarkymas pritaikant jas prie naujų sąlygų technologinio progreso kontekste. Tolimesniuose tyrimuose, įvertinus ir argumentuotai pagrindus mokesčių sistemos pertvarkos galimybes, galima suformuoti rekomendacijas siekiant išlaikyti šalies biudžeto balansą.

Raktiniai žodžiai: 4-oji Pramonès revoliucija, darbo rinka, mokesčiu sistema, robotu apmokestinimas, technologinis progresas.
\end{abstract}

JEL codes: H20, H21.

\section{Ivadas}

Pasaulio Ekonomikos Forumo pirmininkas Klaus Schwab yra pasakęs "Mes esame revoliucijos, iš esmès keičiančios gyvenimo, darbo ir tarpusavio santykius, pradžioje. Savo mastu, apimtimi ir sudètingumu tai, ka laikau 4-taja Pramonès Revoliucija, skiriasi nuo visko, ka žmonija yra patyrusi lig šiol'. 4-oji Pramonès revoliucija pradejjo naują žmonijos raidos etapą, kuris pasižymi greitu, giliu ir plačiu skaitmeninių technologijų ịsiskverbimo lygiu į kasdieninę santvarką. Šios revoliucijos sukeliami padariniai yra šios dienos aktualija veikianti beveik kiekvieną sritị.

Valstybès, siekdamos sukurti darnias mokesčių sistemas, skatinančias ekonomikos plètrą, užtikrinančias stabilias biudžeto pajamas, teisingą ir proporcingą mokesčių paskirstymą, turi adaptuotis prie technologinio progreso kuriamų pokyčių, išnaudoti jų teikiamą potencialą bei rasti būdus ir sprendimus neigiamų padarinių eliminavimui. 4-oji Pramonès revoliucija atveria naujas galimybes verslui ir visuomenei, tačiau sukuria iššūkius mokesčių sistemoms, kurios turi sėkmingai funkcionuoti ir atlaikyti tokius iššūkius, kaip spartėjanti aplinkos kaita, tarptautiškumas ir inovacijų i̊siskverbimas ị visas ekonomines ir socialines veiklos sritis.

Mokesčiu sistemos pertvarkymai 4-osios Pramonès revoliucijos sąlygoto technologinio progreso kontekste yra nauja tema moksliniuose tyrimuose, mokslininkų ir tarptautinių organizacijų ekspertų pabrèžiami kaip itin aktualūs. Mokslininkai (Collin ir Collin (2013), Li (2015), Peng (2016), Olbert ir Spengel (2017), Albert et al., (2018), Devereux ir Vella (2018)) ir tarptautinių organizacijų - Ekonominio bendradarbiavimo ir pletros organizacijos (toliau - EBPO, angl. OECD), Pasaulio banko, Europos Sajungos komisijos ekspertai vienareikšmiškai sutaria, kad technologinè pažanga atneša didžiulius pokyčius ị šiandienos pasaulị ir diskutuoja apie teigiamus bei neigiamus padarinius.

Copyright (C) 2020. Published by Vytautas Magnus University. This is an open access article distributed under the terms of the Creative Commons Attribution Non-Commercial 4.0 (CC BY-NC 4.0) license, which permits unrestricted use, distribution, and reproduction in any medium provided the original author and source are credited. The material cannot be used for commercial purposes. 
Mokslininkų išskiriami teigiami padariniai - technologinis progresas, pramonès ir bendras ekonomikos augimas, rutininių darbų mažèjimas, tačiau yra ir neigiamų padarinių - būtinybė keisti valstybių valdymo reguliavimą dẻl globalinių procesų, dẻl automatizacijos procesų augantis nedarbo lygis ir technologijų įsiskverbimo sąlygoti iššūkiai vertybių sistemai bei finansiniams valstybių reikalams. Sprendimus šiems iššūkiams spręsti siūlo mokslininkai Bal (2015), Bottone (2017), Oberson (2017), Guerreiro et al., (2017), Abbott ir Bogenschneider (2018) ir tarptautinių organizacijų ekspertai. Šiame tyrime išskiriama ir analizuojama mokesčių sistemų pokyčių problema dèl technologinio progreso sukeliamų padarinių viešiesiems finansams. Mokslininkų tyrimuose analizuojama mokesčių sistemų pertvarkymo ar tobulinimo būtinybė, naujų mokesčių, pavyzdžiui, robotų, ịvedimas ir esamų mokesčių, pavyzdžiui, aplinkosauginių, koregavimas. Tarptautinių organizacijų ekspertai ir verslininkai taip pat pritaria šiam mokslininkų požiūriui ir iškeltoms problemoms.

Analizuojant mokslinius tyrimus šia tema, pastebėta, kad trūksta kompleksinès analizès ir išsamių tyrimų dèl mokesčių sistemos pertvarkymo esant dabartiniam sparčiam technologijų progresui. Trūksta scenarijų modeliavimo ir sąveikos tyrimų priimant vienokị ar kitokị sprendimą konkrečioje šalyje ir pasekmių vertinimui vietiniu ir globaliu mastu.

Tai patvirtina nagrinejjamo objekto - mokesčių sistemos pertvarkos kryptys dèl 4-osios Pramonès revoliucijos keliamų iššūkių, problemiškumą. Identifikuota probleminè situacija suteikia galimybę suformuluoti mokslinę problemą klausimu: Kokios galimos mokesčiu sistemos pertvarkos kryptys 4-osios Pramonès revoliucijos iššükiu kontekste, siekiant užtikrinti pakankamas mokestines pajamas?

Tyrimo tikslas - identifikuoti 4-osios Pramonès revoliucijos keliamus iššūkius mokesčių sistemai ir galimas pertvarkos kryptis. Tikslui pasiekti iškelti šie uždaviniai: išnagrinèti 4-osios Pramonès revoliucijos konceptą ir poveiki viešiesiems finansams, identifikuoti 4-osios Pramonès revoliucijos iššūkius mokesčių sistemoms bei teoriškai pagrịsti galimas pertvarkos kryptis.

Atliekant tyrimą buvo naudojami tokie teoriniai metodai: mokslinès literatūros analizè, lyginamoji analizè, sisteminè analizé, dokumentų analizé, apibendrinamoji analizè bei kiti bendramoksliniai metodai. Analizuojant 4-osios Pramonès revoliucijos konceptą, sisteminant šios revoliucijos keliamus iššūkius mokesčių sistemai ir pertvarkos kryptis naudojami operacionalizacijos, sisteminès analizès, indukcijos ir dedukcijos metodai. Mokslinei problemai analizuoti ir pagrịsti naudoti mokslininkų atlikti tyrimai, publikuoti moksliniuose leidiniuose tarptautinèse duomenų bazèse bei tarptautinių organizacijų ekspertų ataskaitos.

Straipsnyje identifikuoti 4-osios Pramonès revoliucijos iššūkiai mokesčių sistemai ir galimos pertvarkos kryptis nurodo mokesčių sistemos tobulinimo linkmę, siekiant ekonominès ir socialinès naudos valstybei ir visuomenei. Tolimesniuose tyrimuose, ivertinus ir argumentuotai pagrindus mokesčių sistemos pertvarkos dèl technologinès pažangos padarinių galimybes, galima suformuoti rekomendacijas siekiant išlaikyti šalies biudžeto balansą. Tokiu atveju, mokesčių sistemos pertvarka būtų tinkama ir kryptinga, atsižvelgianti ị technologinių inovacijų galimybes ir sukeliamas rizikas, užtikrinanti sklandesnị ir spartesnị gerovès valstybės vystymąsị.

\section{Tyrimo rezultatai ir jų aptarimas}

4-oji Pramonès revoliucija, kaip diskusijų ir mokslinių tyrimų tema, paplito po 2016 metų vykusio Pasaulio ekonomikos forumo Davose, Šveicarijoje, kuris simbolizuoja 4-osios Pramonès revoliucijos iniciaciją - žmonijos raidos etapą, kuriame technologinė pažanga ir skaitmeninimas iš pagrindų keičia esamą santvarką (Schwab, 2017).

4-oji Pramonès revoliucijos konceptas remiasi technologijomis, apimančiomis kiber-fizikines sistemas, daiktų internetą ir paslaugų internetą (Ning ir Liu, 2015) ir grindžiamas nuolatiniu komunikavimu internetu, kuris leidžia nepertraukiamai keistis informacija ne tik tarp žmonių, bet ir žmonių bei mašinų, ar tik tarp pačių mašinų (Cooper ir James, 2009). 4-oji Pramonès revoliucija 
šiandien yra tik pradiniame plètros etape ir jos pagrindinių laimèjimų galima tikètis ne anksčiau kaip 2020-2025 metais (Rüßmann et al., 2015).

Ši revoliucija sąlygoja didžiuli postūmị ịvairiems pokyčiams, kurių kryptị ir mastą sudètinga prognozuoti. Gausus skaitmeninių technologijų prieinamumas ir globalumas ịgalina didesnę sąveiką tarp visuomenès narių ịvairiais gyvenimo aspektais. Technologinis progresas vis labiau keičia žmogaus aplinką ir ịpročius, bendravimą tarpusavyje ir saviugdos būdus, požiūrị ir siekius bei reikalauja nuolatinio tobulejjimo, siekiant adaptuotis besikeičiančioje realybèje.

4-oji Pramonès revoliucija turès reikšmingą poveikį pasaulio ekonomikai, o šio poveikio pagrindas yra fizinio ir virtualiojo pasaulio suartejimas (Kagermann, 2015). Jis bus toks didžiulis ir daugialypis, kad sunku bus atskirti vieną konkretų efektą nuo kito, o jo rezultatas turès lemiamą reikšmę konkurencingumui ir bendram ekonominiam augimui (Schwab, 2017). 4-oji Pramonės revoliucija pasižymi sparčia pažangių skaitmeninių technologijų plètra ir ekonomikos globalizacijos procesų pagreitinimu. Šiandien informacinių technologijų plètra vaidina dideli vaidmenị ekonomikoje - žmogus visada siekia patenkinti vis augančius poreikius vienoje ar kitoje veiklos srityje, o informacinès technologijos plečia šių galimybių spektrą. Skaitmenizacijos procesai suformavo visiškai naujus verslo modelius, tokius kaip elektroninè prekyba, internetinès mokèjimų sistemos, internetinè reklama, bei sukūrẻ tokius verslo gigantus, kaip Amazon, PayPal ar Google. 4oji Pramonès revoliucija jau pakeitè ne tik verslo modelius ir vartotojų elgseną šiuolaikinëje ekonomikoje, bet ir sukūrè pagrindą aukštomis technologijomis paremtai ekonominès veiklos plètrai. Ši elektroninès sąveikos pagrindu sukurta infrastruktūra tampa nauja pasaulinès ekonomikos vystymosi kryptimi, kurioje visa ekonominė veikla grindžiama skaitmeninemis technologijomis.

Ši revoliucija turès lemiamą ịtaką ne tik bendram ekonomikos augimui, bet ir darbo rinkai ir užimtumui visame pasaulyje dèl vis platesnio technologijų taikymo ekonominèje veikloje (World Economic..., 2018). Robotai, dirbtinis intelektas ir didelis duomenų srautas bus visų pasikartojančių procesų ir darbų automatizavimo varikliai, perdisponuojantys daugelio pareigų ir profesijų išnykimą (Telefonica, 2017), o naujų technologijų diegimas sukurs naujas darbo vietas (Rajnai ir Kocsis, 2017). Naujosios technologijos pakeis daug darbo vietų, paveiks darbo rinkos struktūrą, būsimų ígūdžių paklausą ir darbo vietas (Kergroach, 2017).

4-oji Pramonès revoliucija keičia ekonomikos vystymosi kryptis bei kelia naujus iššūkius valstybių valdymui visame pasaulyje. Valstybès turi spręsti ne tik su skaitmenizacijos padariniais susijusius klausimus, bet ir sukurti bei vykdyti nacionalines strategijas, kuriose turi būti atsakas $\mathfrak{i}$ naujus viešojo administravimo ir reguliavimo iššūkius, pvz. užimtumo rèmimo; saugumo ir privatumo apsauga; technologinio progreso skatinimas ir pan. Visa tai reikalauja lěšų, kurių pagrindinis šaltinis yra mokesčiai. Tinkama ir efektyvi mokesčių sistema yra vienas pagrindinių mechanizmų lemiančių ekonomikos plètrą ir užtikrinančių svarbiausių valstybės funkcijų vykdymą. Kiekvienos valstybès ekonominei ir socialinei gerovei ịtakos turi surenkamų mokesčių dydis, todèl kiekviena valstybė turi turèti mokesčių sistemą, kuri užtikrintų pajamų surinkimą i šalies biudžetą, o surenkamų mokesčių dydis būtų pakankamas valstybès ir jos gyventojų poreikių tenkinimui.

4-osios Pramonès revoliucija dvejopai veikia mokesčių sistemą - iš vienos pusès technologinis progresas kuria naujas priemones mokesčių administravimui ir galimybes jų surinkimui, iš kitos pusès - keičia mokesčių mokètojų elgseną ir didina su tuo susijusias mokesčių mokèjimo rizikas. Nesant orientuotai i 4-osios Pramonès revoliucijos kuriamą aplinką mokesčių sistemai, mokesčių administratoriai turi taikyti neatitinkančias laikmečio taisykles, sukurtas ne naujajam skaitmeniniam pasauliui, kas lemia asimetriją, dvigubą mokesčių naštą, jų vengimą ir nepakankamas mokestines ịplaukas ị šalies biudžetą ( $\mathrm{Li}, 2015)$.

Mokesčiu sistemos problematika 4-osios Pramonès revoliucijos kontekste analizuojama Collin ir Collin (2013), Li (2015), Peng (2016), Prisecaru (2017), Olbert ir Spengel (2017), Devereux ir Vella (2018) ir kitų. Apibendrinus šių autorių mokslines publikacijas, galima išskirti penkis esminius iššūkius mokesčių sistemoms (žr. 1 pav). 


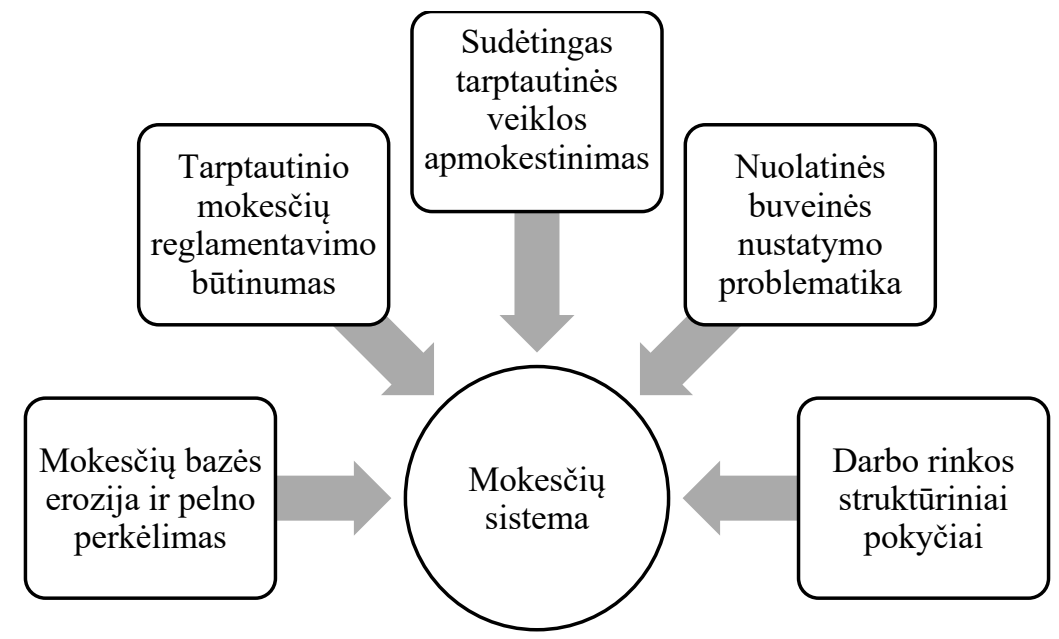

\section{1 pav. 4-osios Pramonès revoliucijos iššūkiai mokesčių sistemai}

Nacionalinei ir tarptautinei mokesčių teisei reikia susidoroti su 4-osios Pramonės revoliucijos padariniais, tokiais kaip pelno mokesčio bazès erozija ir pelno perkèlimas (Collin ir Collin, 2013). Remiantis mokslininkų Li (2015) ir Peng (2016) tyrimais, būtina rasti sprendimus pertvarkant mokesčių sistemas, kurie padètų užkirsti kelią apmokestinamojo pelno perkèlimui i šalis, kur bendrovès realiai nevykdo jokios veiklos, tačiau palankesnis apmokestinimas.

Nagrinèjant ši klausimą pirmiausia susiduriama su nuolatinès buveinès nustatymo problematika. Pagal dabartinį mokesčių reglamentavimą gautas pelnas pirmiausia priskiriamas jurisdikcijai, kurioje yra įmonè ir kur yra registruotas jos turtas. (Olbert ir Spengel, 2017). Skaitmenizacija padidino verslo internacionalizaciją, todèl dabar valdytojai ir vartotojai gali būti įsikūrę skirtingose šalyse, o pati įmonè gali vykdyti veiklą per sudètingas vertès kūrimo grandines, apimančias daugeli šalių, kas smarkiai apsunkina nuolatinès buveinès nustatymą (Devereux ir Vella, 2018).

Mokesčio bazès erozija ir pagrindinès buveinès nustatymo problemos atsispindi didèjančiame visuomenès ir politikų susirūpinime dèl strategijų, kurias naudoja tarptautinès įmonès siekdamos išnaudoti esamą sistemą tam, kad sumažintų savo mokestinius įsipareigojimus (Devereux ir Vella, 2018). Esamos mokesčiu sistemos nèra efektyvios, nes jose nepakankamai ịvertinamas tarptautiškumas, o siekiant pašalinti spragas iprastai padideja reglamentavimo sudėtingumas. (Devereux ir Vella, 2018). Komplikuotas mokesčių reglamentavimas, teisinès bazès kaita apsunkina mokesčių mokètojų sprendimų prièmimą ir planavimo galimybes bei lemia daugelị klaidų. Dauguma šalių bando išspręsti šias problemas savarankiškai, tačiau tai neduoda pakankamo efekto, nes veikla vykdoma virtualioje interneto erdveje, o norint veiksmingai reguliuoti reikalingos atitinkamos tarptautinès taisyklès ir mokesčių istatymų suvienodinimas globaliu mastu.

Dar vienas 4-osios Pramonès revoliucijos iššūkis mokesčių sistemai susijęs su darbo mokesčių surinkimu. Pasak Prisecaru (2017), technologinis progresas, skaitmenizacija ir robotizacija gali turèti neigiamą poveikį darbo rinkai, mokesčių pajamoms nuo darbo užmokesčio ir valstybinių pensijų fondų ịplaukoms. Remiantis EBPO, darbuotojų pakeitimas robotais gali sukelti mokestinių pajamų praradimą, nes darbo mokesčiai yra reikšmingas biudžeto ịplaukų šaltinis. Jeigu žemos kvalifikacijos ar ịprastus darbuotojus pakeis robotai, o valstybė neinvestuos ị jų perkvalifikavimą, padidès nedarbas ir socialinè nelygybè. Nors nèra vieningos nuomonès apie nedarbą, kuri gali sukelti 4-oji Pramonès Revoliucija, akivaizdu, kad dèl technologinio progreso reikès didesnių investicijų ị švietimą ir perkvalifikavimo mokymus, o viešujų finansų poreikis ateityje tendencingai didès (OECD, 2018). Azijos vystymosi bankas savo ataskaitoje dèl 4-osios Pramonès revoliucijos poveikio integracijai taip pat numato, kad darbo vietų praradimas turès neigimą įtaką mokesčių pajamoms ir tikètina, kad padidès bendra socialinè žala, prarastų darbo vietų ir pajamų bei mažèjančio BVP pasekmè (World Economic..., 2017). Europos Komisijos ataskaitoje (2019) teigiama, kad socialiai pažeidžiamų grupių padidejjimas reiškia didesnę socialinių išmokų paklausą ir mažèjančias mokestines ịplaukas. Albert et 
al., (2018) teigia, kad tikslinga mokesčiu reforma gali padengti visas socialinès apsaugos ir žmogiškojo kapitalo ugdymo išlaidas. Reformos metu svarbu numatyti geresnį pajamų ir pelno mokesčių surinkimą, įvairių subsidijų reformų inicijavimą ir mokesčių vengimo mažinimą.

Tačiau bet kokia mokesčių sistemos pertvarka pirmiausia turètų vykti atsižvelgiant i pagrindinius apmokestinimo principus. Tačiau ir patys principai turètų būti peržiūrèti, atsižvelgiant skaitmenizacijos pasekmes, pvz. neutralumo principas turètų būti papildytas - mokesčių sistema turi būti neutrali elektroninio ir "tradicinio" verslo atžvilgiu; lankstumo principas - mokesčių sistema turi būti dinamiška ir neatsilikti nuo technologinio progreso.

Mokesčių sistemos iššūkių sprendimas skaitmenizacijos kontekste yra ịvairių tarptautinių organizacijų tyrimų ir diskusijų objektas. Reikšmingiausias indèlis į šios problemos sprendimą yra 2015 metais EBPO mokesčių bazès erozijos ir pelno perkèlimo projektas (angl. Base erosion and profit shifting, toliau - BEPS).

BEPS projekte išskiriami esminiai iššūkiai mokesčių sistemoms, kuriuos sukèlè 4-osios Pramonès revoliucijos varomas skaitmeninès ekonomikos augimas "Skaitmeninei ekonomikai būdinga didele priklausomybè nuo nematerialiojo turto, masinis duomenu (ypač asmens duomenu) naudojimas, plačiai taikomi tarptautiniai verslo modeliai, gaunantys vertés iš nemokamu produktu ir vertès kürimo vietos nustatymo problematika. Tai kelia pagrindinius klausimus, kaip skaitmeninès ekonomikos įmonès sukuria pridètinę verte ir uždirba pelna, ir kaip skaitmeninejje ekonomikoje turi büti traktuojamos veiklos vykdymo vietos squvoka ar apmokestinimo mokesčiais tikslais " (OECD, 2014).

Šie iškelti klausimai yra dažnai kvestionuojami ir sprendžiami mokesčių administratorių bei politikų visame pasaulyje. BEPS projektas kuria naujas pelno apmokestinimo normas ir siūlo nemažai priemonių, kurias šalys turètų igyvendinti kovai su pelno mokesčio vengimu ir siekiant užtikrinti sąžiningą mokesčių konkurenciją visame pasaulyje (Europos Komisija, 2016).

Siekiant tobulinti mokesčių sistemą 4-osios Pramonès revoliucijos kontekste BEPS projektas numato 15 veiksmų trijose kryptyse - darnumo, turinio, skaidrumo bei lankstumo. Darnumo kryptis numato neatitikimų tarp šalių mokestinių sistemų mažinimą; turinio - kad pajamos būtų apmokestintos ten, kur įmonè realiai vykdo veiklą ir sukuria vertę, o ne pagal registracijos vietą; skaidrumo ir tikslumo kryptis numato informacijos keitimąsi tarp mokesčius administruojančiu institucijų ir efektyvesnị mokestinių ginčų sprendimą (OECD, 2014). Visa tai sudaro prielaidą nacionalinėms bei tarptautinėms taisyklèms ir priemonèms skirtoms kovoti su mokesčių vengimu ir užtikrinančiomis teisingą apmokestinimą (Olbert ir Spengel, 2017).

Neskaitant BEPS projekto, šalys ir kitos tarptautinès organizacijos imasi mokesčių sistemos pertvarkos bandydamos prisitaikyti prie naujų realijų. Mokslinèje literatūroje ir tarptautinių organizacijų ataskaitose išskiriamos dvi priešingos mokesčių sistemos pertvarkos kryptis (žr. 2 pav):

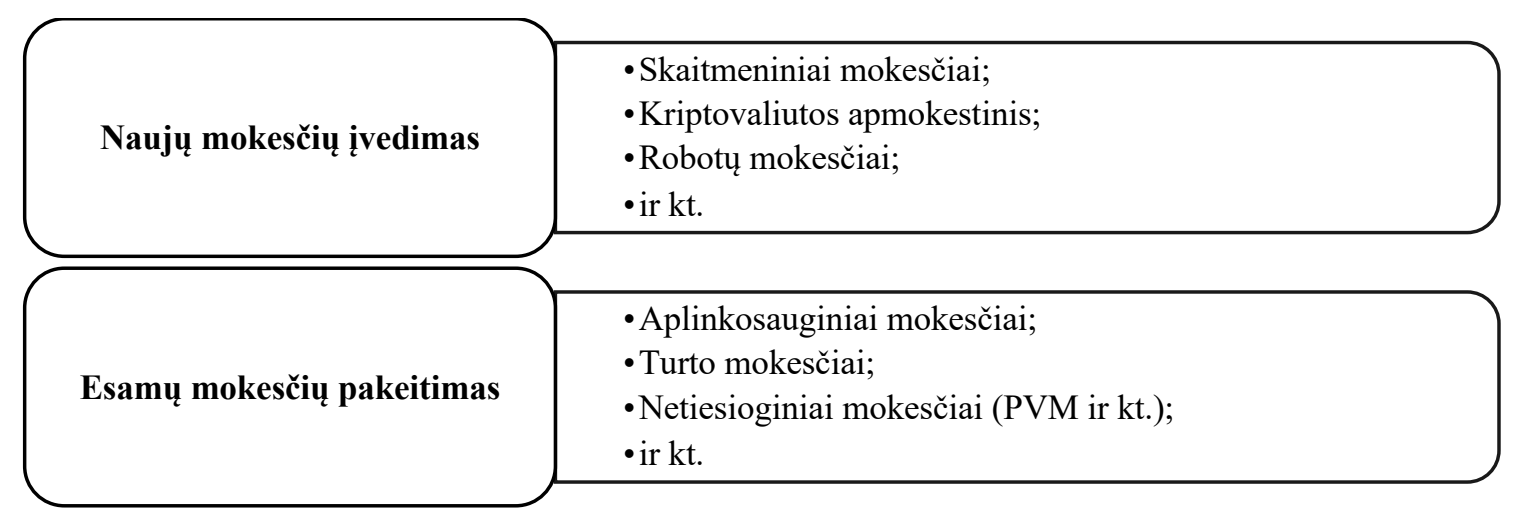

\section{2 pav. Mokesčių sistemos pertvarkos kryptys}

Vienas naujų mokesčių pavyzdžių yra skaitmeninis mokestis Europos Sajungoje, kuris mokamas nuo trijų tipo pajamų: reklamos internete, vartotojų ar prenumeratorių ir surinktų duomenų 
pardavimo pajamų. Numatomas mokesčio tarifas yra 3 proc. (Europos Vadovų..., 2019). Šis mokestis orientuotas i didžiausias skaitmenines bendroves, tokias kaip Google, Facebook ir pan. Dèl šio mokesčio jau dabar kyla labai daug diskusijų, argumentuojant tuo, kad tai pažeidžia neutralumo principą, kadangi tarptautinès bendrovès bus apmokestinamos daugiau nei ES bendrovès. Numatoma ir neigiama šio mokesčio ịvedimo pusè - kainų padidejjimas ir ES konkurencingumo sumažejjimas.

Kitas skaitmeninès veiklos mokesčio pavyzdys - Jungtinèje Karalystejje įvestas koreguojantis pelno mokestis. Šio mokesčio tikslas yra kovoti su tarptautinių įmonių mokesčių mokèjimo vengimu. Jis koreguoja mokesčių mokètojų elgseną, skatindamas juos mokėti mokesčius ne užsienio šalyse, o Didžiojoje Britanijoje. Šio mokesčio dydis yra 25 proc., o jo apmokestinamoji bazė yra pelno dalis, kuri laikoma dirbtinai nukreipta iš Jungtinès Karalystès ir kuri nustatoma tam tikrais testais ir reikšmėmis (HM revenue..., 2017).

Siūloma apmokestinti blokų grandinès (angl. blockchain) technologiją. Tačiau toks kriptovaliutos apmokestinimas sukuria mokesčių sistemai ir galimybių, ir iššūkių. Viena vertus, kriptovaliutos yra nereguliuojamos ir jų neprižiūri nei vienas centrinis bankas, o tai reiškia, kad yra labai sudėtinga kontroliuoti šią technologiją. Kita vertus, tai sukuria naujas technines galimybes integruoti naujus apmokestinimo mechanizmus pačioje blokų grandinèje (Schwab, 2017). Kriptovaliutų apmokestinimas kelia ir kitas problemas - švietimo, apmokestinimo bazès nustatymo ir PVM taisyklių taikymo. Mokesčių mokètojams reikia praktinių rekomendacijų dèl jų vykdomos veiklos apmokestinimo. Svarbu nustatyti pačią apmokestinimo bazę, atsižvelgiant ị kriptovaliutos technologiją. PVM taikymui neaiški yra apmokestinamojo asmens sąvoka, registravimosi kriterijų taikymas ir vietos nustatymas (Bal, 2015).

Naujas mokestis, galintis padèti kompensuoti skaitmenizacijos padarinius galètų būti robotų mokestis. Šiai idejjai pritaria visuomenininkai, pavyzdžiui, kompanijos Microsoft įkūrèjas Bill Gates, tarptautinès organizacijos, pavyzdžiui, Europos Parlamentas, ir ịvairūs mokslininkai. Robotų apmokestinimas galètų vykti, suteikiant robotams tam tikrą mokestini statusą ir apskaičiuojant pajamų mokestį nuo sąlyginio atlyginimo gauto iš robotų veiklos (Oberson, 2017). Kitas pasiūlymas yra apmokestinti hipotetinį robotų atlygị, kurị gautų žmogus, jeigu jis dirbtų toje darbo vietoje. Toks robotų pajamų mokestis teisinamas ekonominiu pranašumu, kurị darbdavys igyja dèl robotu naudojimo vietoje darbuotojų (Guerreiro et al., 2017). Šioje perspektyvoje galima numatyti, kad vèliau, tobulèjant technologijoms, robotai gali igyti "asmens" statusą ir turètų būti apmokestinami siekiant susigrąžinti sumažejusias mokesčiu pajamas dèl darbo jègos pakeitimo (OECD, 2018). Abbott ir Bogenschneider (2018) teigia, kad mokesčių sistema turètų būti „,neutrali““ tarp robotų ir žmonių, o automatika neturètų mažinti mokesčių îplaukų. Tai galètų būti pasiekta sukuriant ,automatizavimo mokestį“, kuris atspindètų esamas nedarbo schemas, suteikiant kompensacines lengvatas žmonėms ir padidinant pelno mokesčio tarifą (Abbott ir Bogenschneider, 2018).

Nors robotų apmokestinimo galimybès yra numatomos ir įžvelgiamos teigiamos tokio sprendimo pusès, tačiau yra ir neigiamos pasekmès. Bottone (2017) nagrinèdama robotuc apmokestinimo problematiką teigia, kad robotų apmokestinimo klausimas yra labai prieštaringas, nes tai gali suaktyvinti mokesčių konkurenciją tarp skirtingų regionų, todèl reikia šią temą įtraukti i tarptautinius susitarimus dèl bendrų apmokestinimo taisyklių, kuriais siekiama kovoti su mokesčių slèpimu ir vengimu. (Bottone, 2017). Robotu apmokestinimas gali turèti ir daugiau neigiamų pasekmių: robotų apmokestinimas gali sulètinti investicijas i automatizavimą taip pristabdant ekonomikos augimą, atgrasyti nuo naujovių ir dar labiau pabloginti žmonių, praradusių darbą, padėti, nes tokie žmonès irgi yra vartotojai, o apmokestinimas padidins vartojimo produktų kainas (Telefonica, 2017). Bet kokiu atveju, robotu paplitimas ir platus taikymas ateityje neabejotinai pareikalaus pokyčių mokestinejje sistemoje, galimai jas papildant robotų apmokestinimu, tačiau svarbu įvertinti visas pasekmes.

Mokslininkai diskutuoja dèl naujų mokesčių ịvedimo būtinybès ar esamų tobulinimo. Kai kurie mokslininkai teigia, kad nereikètų įvesti naujų mokesčių, o adaptuoti esamas mokesčių sistemas naujoms sąlygoms. Pavyzdžiui, Oueslati (2013) išanalizavęs aplinkosauginių mokesčių poveikio ilgalaikius ir trumpalaikius efektus augančioje ekonomikoje nustatė, kad mažinant darbo pajamų 
procentinę dalị ir padidinant aplinkosauginių mokesčių dalị BVP, skatinamas ekonomikos augimas ir keliama bendra šalies gerovè. Tai teigiamas ilgalaikis mokesčio poveikio efektas. Tiesa, aplinkosauginiai mokesčiai turi neigiamą trumpalaiki efektą, kuris pasireiškia per šalies konkurencingumo mažèjimą. Aplinkosauginiai mokesčiai galètų būti geras fiskalinès politikos instrumentas, ženkliai prisidedantis prie aplinkos išsaugojimo ir pritraukiantis ị šalies biudžetą papildomas pajamas, kurias galima būtų paskirstyti 4-osios Pramonès revoliucijos neigiamiems padariniams, užimtumui mažinti.

Turto mokesčiai yra antras apmokestinimo būdas, kurį reikètų apsvarstyti kaip priemonę kompensuoti sumažejjusius mokesčius. Šią galimybę siūlo Pasaulio ekonomikos forumas (OECD, 2018) nurodydamas, kad prabangaus turto apmokestinimas prisidėtu prie nelygybès mažinimo ir užtikrintų papildomas ịplaukas ị šalies biudžetą. Tačiau turto mokesčio padidinimas turi ir neigiamų padarinių - visų pirma, bus apmokestintas ir darbo netekusiųjų turtas, antra, norint eliminuoti pirmają problemą, ịvairios lengvatos apsunkins mokesčio administravimą, trečia - turto mokesčiai paprastai yra vietos mokesčiai, t.y. mokami i vietos savivaldos instituciją ir sudaro nemažą šios institucijos pajamų dali.

4-osios Pramonès revoliucijos kontekste aktualu ịvertinti ir poveikị netiesioginiams mokesčiams - pridètinès vertès mokesčiui. Nors ir šio mokesčio reglamentavimo tobulinime padaryta pažanga, vis dẻlto yra išlikusių techninių problemų (Collin ir Collin, 2013). Būtina užtikrinti veiksmingą PVM rinkimą tiekiant prekes ir paslaugas tarptautinei rinkai, o tai galima pasiekti tik identifikavus ir įvertinus kitų mokesčių ir PVM problemų sąsajas.

Bet kokiu atveju, negalima kalbèti apie šių scenarijų taikymą tik vienos šalies mastu, nes tai gali smarkiai sumažinti konkurencingumo galimybes ir duoti priešingą efektą - ekonomikos nuosmukị, vartojimo mažejjimą ir didèjantị nedarbą. Šie sprendimai gali būti priimami tik globaliu mastu, esant tarptautiniam sutarimui ir tik po išsamių mokslinių tyrimų.

\section{Išvados}

4-ają Pramonès revoliuciją galima laikyti šiuolaikinio ekonominio, socialinio ir kultūrinio progreso terpę, kurioje visi vykstantis evoliucijos procesai paremti skaitmeninėmis sistemomis. Šis progresas keičia mums įprastus ekonominius modelius, rinkos dalyvių elgseną ir ateityje numato dar didesnius ir spartesnius pokyčius. Šių pokyčiai reikalauja greitų ir savalaikių sprendimu, ypatingai valstybès valdyme. Juk nuo šių sprendimų priklauso šalies konkurencingumas ir piliečių gerovè. Darni mokesčių sistema padètų užtikrinti pakankamas biudžeto ịplaukas ir garantuotų lěšas šių sprendimų igyvendinimui. Mokesčių sistemos, kaip valstybės fiskalinès funkcijos instrumento, pertvarkos tikslas turètų būti optimalios mokesčiu sistemos kūrimas, kuri galètų sèkmingai funkcionuoti 4-osios Pramonès revoliucijos kontekste.

4-oji Pramonès revoliucija kelią iššūkius pačios mokesčių sistemos pagrindui - apmokestinimo principams, kurie turi būti peržiūrèti ir papildyti atsižvelgiant ị naujas realijas. Dèl technologinio progreso taip pat turi būti pakeistos apmokestinimo taisyklès, atsižvelgiant ị šiuos iššūkius: mokesčių bazès erozija ir pelno perkèlimas, nuolatinès buveinès nustatymo problematika, tarptautinio mokesčių reglamentavimo būtinumas, sudètingas tarptautinès veiklos apmokestinimas ir darbo rinkos struktūrinių pokyčių programuojamas valstybės biudžeto disbalansas. Senų principų ir apmokestinimo taisyklių taikymas lems mokesčių vengimą, nepakankamą mokestinių pajamų surinkimą ir bendrą ekonomikos lètejjimą. Keičiant apmokestinimo taisykles didžiulę reikšmę igauna jų derinimas globaliu mastu ir tarptautinis bendradarbiavimas, siekiant užtikrinti sąžiningą mokesčių konkurenciją visame pasaulyje. Pati 4-osios Pramonès revoliucijos esmè - skaitmenizacija "be sienų", ne tik diktuoja ši poreikị, tačiau ir yra instrumentas tokios mokesčių politikos ígyvendinimui.

Numatomos dvi mokesčių sistemų tobulinimo kryptys: naujų mokesčių ịvedimas ir esamų mokesčių sistemų pertvarkymas pritaikant jas prie naujų sąlygų technologinio progreso kontekste. Tačiau bet kokiam apmokestinimo keitimo sprendimui pagrịsti reikia atlikti išsamią analizę, kuri tirtu 
mokestinių pakeitimų sąveiką su kitais mokesčiais, įtaką mikro- ir makro- aplinkoms, funkcionalumą ir ilgaamžiškumą. Šiuos tyrimus apsunkina 4-ajai Pramonès revoliucijai būdingi faktoriai globalumas, nepastovumas ir inovatyvumas.

\section{Literatūros sąrašas}

Abbott, R., \& Bogenschneider, B. (2018). Should robots pay taxes: Tax policy in the age of automation. Harv. L. \& Pol'y Rev., 12, 145.

Albert, J. R. G., Orbeta Jr, A. C., Paqueo, V. B., Serafica, R. B., Dadios, E. P., Culaba, A. B., ... \& Bairan, J. C. A. C. (2018). Harnessing government's role for the Fourth Industrial Revolution.

Bal, A. (2015). How to Tax Bitcoin?. In Handbook of digital currency (pp. 267-282). Academic Press.

Bottone, G. (2018). A tax on robots? Some food for thought (No. 3). DF Working Papers.

Brynjolfsson, E., \& McAfee, A. (2012). Race against the machine: How the digital revolution is accelerating innovation, driving productivity, and irreversibly transforming employment and the economy. Brynjolfsson and McAfee.

Collin, P., \& Colin, N. (2013). Task Force on Taxation of the Digital Economy. Report to the Minister for the Economy and Finance, the Minister for Industrial Recovery, the Minister Delegate for the Budget and the Minister Delegate for Small and Medium-Sized Enterprises, Innovation and the Digital Economy.

Cooper, J., \& James, A. (2009). Challenges for database management in the internet of things // IETE Technical Review, 26(5), 320-329.

Devereux, M. P., \& Vella, J. (2018). Debate: implications of digitalization for international corporate tax reform // Intertax, 46(6/7).

European Commission (2019). High-level group publishes report on impact of digital transformation on EU labour markets.

https://ec.europa.eu/social/main.jsp?langId=en\&catId=1146\&furtherNews=yes\&newsId=9344 [30 06 2020].

Europos Komisija (2016). Komisijos komunikatas Europos Parlamentui ir Tarybai Veiksmingo apmokestinimo išorès strategija COM/2016/024 final. - https://eur-lex.europa.eu/legalcontent/LT/TXT/HTML/?uri=CELEX:52016DC0024\&from=LT [2020 06 30].

Europos Vadovu Taryba (2019). Skaitmeninio sektoriaus apmokestinimas. https://www.consilium.europa.eu/lt/policies/digital-taxation/ [ 202006 30]

Guerreiro, J., Rebelo, S., \& Teles, P. (2017). Should robots be taxed? (No. w23806). National Bureau of Economic Research.

HM Revenue \& Customs (2018). HMRC annual report and accounts: 2017 to 2018. https://www.gov.uk/government/publications/hmrc-annual-report-and-accounts-2017-to-2018 [30 06 2020].

Kagermann, H. (2015). Change through digitization-Value creation in the age of Industry 4.0. In Management of permanent change (pp. 23-45). Springer Gabler, Wiesbaden.

$11(4$ (eng)).

Kergroach, S. (2017). Industry 4.0: new challenges and opportunities for the labour market. Форсайт,

Li, J. (2015). Protecting the Tax Base in a Digital Economy. United Nations Handbook on Selected Issues in Protecting the Tax Base of Developing Countries.

Ning, H., \& Liu, H. (2015). Cyber-physical-social-thinking space based science and technology framework for the Internet of Things. Science China Information Sciences, 58(3), 1-19.

Oberson, X. (2017). Taxing robots? From the Emergence of an Electronic Ability to Pay to a Tax on Robots or the Use of Robots. World Tax Journal, 9(2), 247-261.

OECD (2014). Addressing the Tax Challenges of the Digital Economy. https://www.oecd.org/tax/addressing-the-tax-challenges-of-the-digital-economy-9789264218789-en.htm [30 06 2020].

OECD (2018). Economic survey USA. - http://search.oecd.org/economy/united-states-economicsnapshot/ [30 06 2020].

Olbert, M., \& Spengel, C. (2017). International taxation in the digital economy: challenge accepted. World tax journal, 9(1), 3-46.

Peng, W. (2016). Multinational Tax Base Erosion Problem of the Digital Economy. Modern Economy, 7(03), 345.

Prisecaru, P. (2017). The challenges of the industry 4.0 // Global Economic Observer, 5(1), 66. 
Queslati, W. (2013). Short and Long-term Effects of Environmental Tax reform. http://ageconsearch.umn.edu/bitstream/146354/2/NDL2013-009.pdf [30 06 2020].

Rajnai, Z., \& Kocsis, I. (2017, September). Labor market risks of industry 4.0, digitization, robots and AI. In 2017 IEEE 15th International Symposium on Intelligent Systems and Informatics (SISY) (pp. 000343000346). IEEE.

Rüßmann, M., Lorenz, M., Gerbert, P., Waldner, M., Justus, J., Engel, P., \& Harnisch, M. (2015). Industry 4.0: The future of productivity and growth in manufacturing industries. Boston Consulting Group, 9(1), 54-89.

Schwab, K. (2017). The fourth industrial revolution. Currency.

Telefonica (2017). Reforming social and tax policies for digital societies. https://www.telefonica.com/digital-manifesto/download_chapter_2.html [30 06 2020].

World Economic Forum (2018). The Future of Jobs. - https://www.weforum.org/reports/the-future-ofjobs-report-2018 [30 06 2020].

World Economic Forum Asian Development Bank (2017). ASEAN 4.0: what does the Fourth Industrial Revolution mean for regional economic integration? - https://www.adb.org/publications/asean-fourthindustrial-revolution-regional-economic-integration [30 06 2020].

\title{
CHALLENGES OF THE 4TH INDUSTRIAL REVOLUTION FOR THE TAX SYSTEM AND THE DIRECTION OF RESTRUCTURING
}

\author{
*Jevgenija Česnausk $\dot{e}^{1}$, Astrida Miceikien $\dot{e}^{2}$ \\ ${ }^{1}$ PhD stud. Vytautas Magnus University, Universiteto str. 10, 53361 Akademija, Kaunas r., Lithuania. \\ E-mail jevgenija.cesnauske@vdu.lt \\ ${ }^{2}$ Prof. dr. Vytautas Magnus University, Universiteto str. 10, 53361 Akademija, Kaunas r., Lithuania. \\ E-mail astrida.miceikiene@vdu.lt
}

\section{Summary}

The 4th Industrial Revolution can be seen as the environment of modern economic, social and cultural progress, in which all current evolutionary processes are based on digital systems. These processes pose challenges for tax systems, such as robotization, digitalization and other technological innovations. The tax system must adapt to the changes caused by the 4th Industrial revolution, use their potential and ensure economic development, stable budget revenues and fair and proportional distribution of taxes. Research problem: what are the possible directions of reforming the tax system in the context of the challenges of the 4th Industrial revolution to ensure sufficient tax revenues? The aim of the study is to identify the problems faced by the tax system because of the 4th Industrial revolution, and possible directions of restructuring. To achieve this aim, the research of scientists and expert opinions of international organizations were analyzed and systematized using the methods of operationalization, systematic analysis, induction, and deduction. The obtained results of the study provide two directions for restructuring tax systems: introduction of new taxes and the reorganization of existing tax systems by adapting them to new conditions in the context of technological progress. Further studies, after assessing and justifying the possibilities of reforming the tax system, can provide recommendations for maintaining a balanced budget of the country.

Keywords: 4th Industrial Revolution, labor market, tax system, rob tax, technological progress.

JEL codes: $\mathrm{H} 20, \mathrm{H} 21$. 